\title{
ERGOGÊNICO CAFEÍNA E ATIVIDADE FÍSICA NA SAÚDE
}

Camila Pasa ${ }^{1}$

Pablo Pasa ${ }^{2}$

\section{INTRODUÇÃO}

$\mathrm{O}$ café foi fortemente introduzido na Europa no século XVI pelos espanhóis e holandeses. Antes disso ele era consumido de forma restrita e a bebida nobre na época era o chá (BARONE; ROBERTS,1984 e MELLO et al., 2007).

A cafeína (trimetilxantina) é um componente comum na dieta de muitos atletas e praticantes de atividade física, pois é consumida naturalmente em alguns alimentos como chocolate, refrigerantes, bebidas energéticas, e o próprio café, ou na forma de suplementos alimentares. Vários estudos tiveram como foco de interesse avaliar os efeitos da cafeína sob diferentes situações, como por exemplo, os possíveis efeitos ergogênicos sobre a resistência, força, tempo de reação e hidratação.

Considerando que a cafeína está presente em muitos alimentos e bebidas, é possível dizer que cerca de $80 \%$ da população geral faz ou já fez o uso dessa substância, embora quantificar seu consumo seja difícil. Nos países latinos o hábito de tomar café é mais evidente e se caracteriza por apresentar um maior teor de cafeína quando comparado com o consumo em outros países (VITORINO et al., 2007).

No entanto, os americanos preferem o café com concentração mais diluída ou mesmo o descafeinado, embora os EUA se encontra entre os maiores consumidores de café do mundo junto com Grã-Bretanha, Itália e Escandinávia (SILVA, 2003).

Mesmo não tendo nenhum valor nutricional, a cafeína resulta em diversos efeitos e dependendo da dosagem eles podem ser benéficos ou não (RANG; DALE, 1993). Quando consumida em

1 Doutoranda do PPGCS em Ciência da Saúde. Faculdade de Medicina. UFMT.pasa camila@hotmail.com

2 Analista de Sistemas. Universidade de Cuiabá. UNIC. papablopasa@gmail.com 
baixas dosagens $(2 \mathrm{mg} / \mathrm{kg})$, a cafeína provoca aumento do estado de vigília, diminuição da sonolência, alívio da fadiga, aumento da respiração, aumento na liberação de catecolaminas, aumento da frequência cardíaca, aumento no metabolismo e diurese (MELLO et al., 2007). Em altas dosagens (15mg/Kg) causa nervosismo, insônia, tremores e desidratação (FETT, 2000).

O estado da arte ganha destaque ao proporcionar informações e conhecimentos de caráter literário, como forma de ampliar os saberes científicos. Desta forma, propiciam aos pesquisadores possibilidades de aprofundarem os conhecimentos sobre os aportes teóricos comprovados cientificamente e reunir um banco dados com reforços na literatura moderna voltado para o interesse da população em geral no que se refere à saúde do ser humano.

\section{DESENHO METODOLÓGICO}

O desenho do estudo corresponde à proposta metodológica ao pesquisar as produções científicas através do estudo de revisão, que propiciam um recorte bibliográfico sobre um tema ao reunir todas as informações de cunho científico, constituindo um banco de dados ou um banco de informações. Esta fonte de informações se constitui a base científica para delinear o objeto de estudo a ser investigado. Desta forma, ao realizar a abordagem envolvendo o estado da arte, que trata de um tema atual, em questão, constitui o impulso científico nos dias atuais sobre saúde e qualidade de vida.

\section{Cafeína}

A ingestão de altas doses de cafeína (10-15 mg/Kg de peso corporal) não é recomendada, pois as concentrações plasmáticas de cafeína podem alcançar valores tóxicos de até $200 \mathrm{~mm}$ (ALTIMARI, 2001).

Os efeitos colaterais causados pela ingestão de cafeína ocorrem em maior proporção em pessoas suscetíveis e que utilizam esta substância em excesso, podendo prejudicar a estabilidade de membros superiores induzindo-os a trepides e tremor, resultando da tensão muscular crônica (FETT, 2000).

Para Wilmore e Costil (1999) as pessoas que utilizam a cafeína se sentem mais fortes e competitivas, acreditam que podem realizar 
um esforço mais prolongado antes que ocorra o início da fadiga e que, caso estejam fatigadas antecipadamente, a fadiga é reduzida.

A cafeína pertence ao grupo das drogas metilxantinas $(1,3,7$ trimetilxantina), do qual também fazem parte a teofilina, a teína, a guaraína e a teobromina. As metilxantinas são alcalóides estreitamente relacionados que se diferenciam pela potência de suas ações farmacológicas sobre o sistema nervoso central - SNC, segundo SPRIET (1995). Nesse sentido a cafeína é uma substância capaz de excitar ou restaurar as funções cerebrais e bulbares, sem, contudo, ser considerada uma droga terapêutica, sendo comumente utilizada e livremente comercializada, por apresentar uma baixa capacidade de indução à dependência (RANG; DALE, 1993).

Os efeitos da cafeína durante o exercício físico estão relacionados principalmente a um aumento na liberação de catecolaminas e mobilização de ácidos graxos, consequentemente resultando em uma diminuída utilização do glicogênio intramuscular como fonte de energia (SILVA, 2003). Esses mecanismos fisiológicos de ação da cafeína poderiam retardar o início da fadiga muscular periférica, contribuindo para um aumento do desempenho físico (VITORINO et al., 2007)

Existem três teorias que podem explicar o efeito ergogênico da cafeína durante o exercício físico: A primeira envolve o efeito direto da cafeína em alguma porção do sistema nervoso central, afetando a percepção subjetiva de esforço ou a propagação dos sinais neurais entre o cérebro e a junção neuromuscular. A segunda teoria pressupõe o efeito direto da cafeína sobre co-produtos do músculo esquelético. As possibilidades incluem: alteração de íons, particularmente sódio e potássio; inibição da fosfodiesterase (PDE), possibilitando um aumento na concentração de adenosina monofosfato cíclica (AMPc) causando um efeito direto sobre a regulação metabólica de enzimas semelhantes às fosforilases (PHOS); e aumento na mobilização de cálcio através do retículo sarcoplasmático, o qual contribui para a potencialização da contração muscular (SPRIET, 1995; RANG e DALE, 1993).

Contudo, a contribuição da PCr durante sprints repetidos é amplamente determinada pela magnitude dos estoques da PCr que são restabelecidos durante os períodos de intervalo (GLAISTER, 2005).

A terceira teoria diz respeito ao aumento na oxidação das gorduras e redução de carboidratos ( $\mathrm{CHO}$ ) e acredita-se que a cafeína 
gera um aumento na mobilização dos ácidos graxos livres dos tecidos ou nos estoques intramusculares, aumentando a oxidação da gordura muscular e reduzindo a oxidação de carboidratos (SPRIET, 1995; MELLO et al., 2007).

Também é possível que o aumento do potencial de oxidação das gorduras promova a economia de glicogênio hepático e muscular, levando a um aprimoramento nos exercícios de endurance e essa hipótese é conhecida como a "teoria poupadora de glicogênio" (MCARDLE et al., 1998), conforme Figura 1.

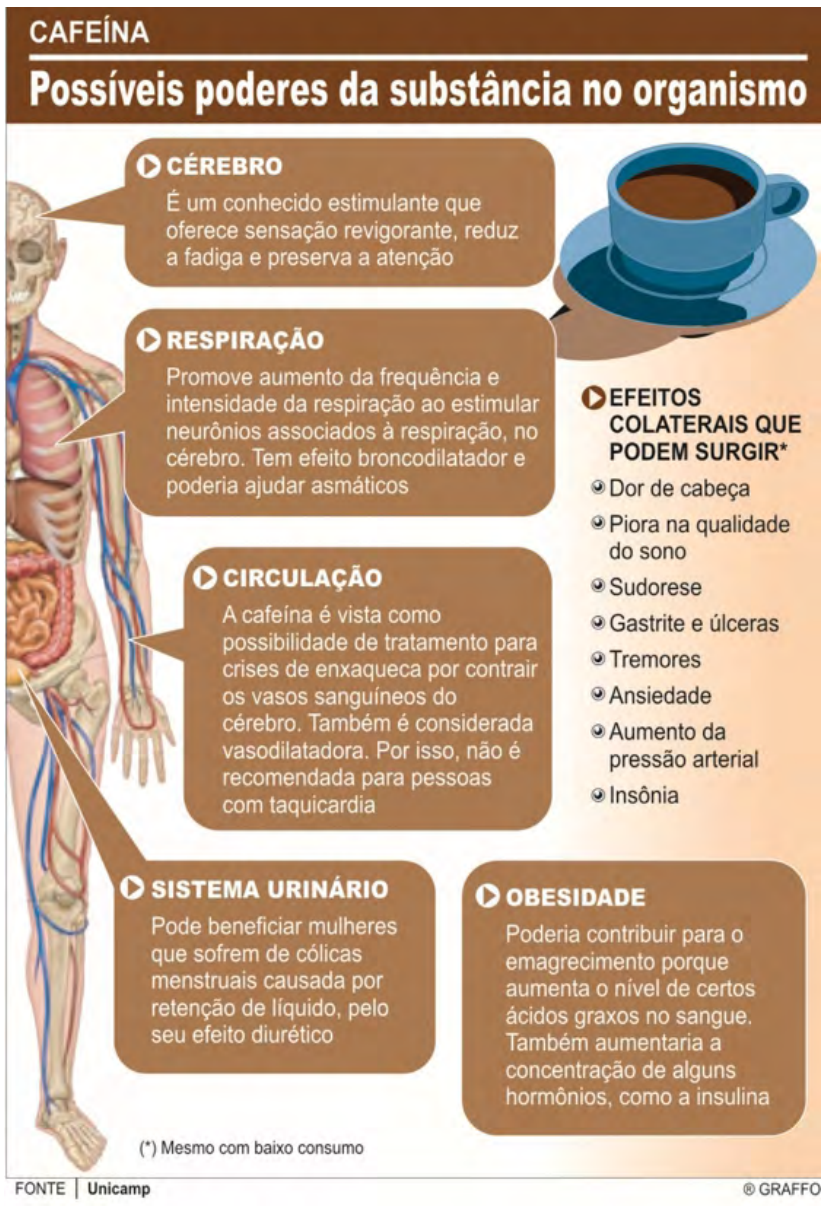

Figura 1. Efeitos da cafeína no organismo humano. 2014

Fonte: UNICAMP. 2014. 
O efeito da lipólise na redução da oxidação de glicose seria importante durante o exercício intenso para as células musculares, uma vez que, baixas concentrações de glicogênio ou altas concentrações de lactato muscular estão diretamente envolvidos com o mecanismo de fadiga muscular (SILVA, 2003)

Embora o aumento da lipólise induzido artificialmente pela cafeína ou por outra estratégia como a infusão de heparina ou ácidos graxos, tem confirmado esta hipótese em diferentes estudos, mas pouco se conhece a respeito desse mecanismo durante o exercício intermitente intenso onde a produção de energia oxidativa deve aumentar à medida que o exercício físico é mantido (SILVEIRA et al., 2004).

Altimari et al., (2000) destaca que o uso da cafeína em exercícios físicos de média e longa duração pode ser capaz de promover uma melhoria na eficiência metabólica dos sistemas energéticos durante o esforço, contribuindo para melhoria do desempenho e também observaram que a dosagem de cafeína é fator determinante na melhoria de desempenho físico, pois o desencadeamento das respostas fisiológicas e metabólicas parece estar atrelado à quantidade ingerida.

Alguns estudos apontam para um relativo aumento da força muscular acompanhado de uma maior resistência à aparição da fadiga muscular após a ingesta de doses relativamente altas de cafeína, embora não se saiba de forma concreta o verdadeiro mecanismo de ação responsável pelo aumento da força muscular. Todavia, acredita-se que isso ocorra em maior intensidade muito mais pela ação direta da cafeína no SNC do que pela sua ação em nível periférico (KALMAR; CAFARELLI, 1999).

Com relação aos exercícios máximos e supramáximos de curta duração, a maioria dos estudos dessa natureza vem demonstrando que a ingestão de cafeína pode melhorar significativamente o desempenho físico (ALTIMARI et al., 2008).

Para Kalmar e Cafarelli (2004) observou-se redução significante na fadiga muscular e estimativa de fadiga central consideravelmente reduzida após ingestão de cafeína $(6 \mathrm{mg} /$ $\mathrm{Kg}$ ). Diante desses achados os pesquisadores sugerem que a fadiga central parece contribuir diretamente para a fadiga neuromuscular. 
O uso de cafeína é relativamente seguro, e não são conhecidos efeitos negativos no desempenho físico, nem tão pouco causa desidratação significativa ou um desequilíbrio eletrolítico durante o exercício (SOARES; FONSECA, 2004).

\section{CONSIDERAÇÕES FINAIS}

O café é uma das bebidas mais consumidas no mundo antigo e no mundo moderno. Esta bebida contém antioxidantes, vitaminas, minerais e algumas proteínas dietéticas, que são benéficas para a saúde. Embora a cafeína tenha efeitos positivos, o consumo excessivo causa resultados negativos, quando se trata da saúde e da qualidade de vida.

\section{REFERÊNCIAS}

ALTIMARI, L.R., FONTES, E. B., OKANO, E. B., TRIANA, R. O. CHACON-MIKAHIL, M. P. T., MORAES, A. C. de A ingestão de cafeína aumenta o tempo para fadiga neuromuscular e desempenho físico durante exercício supramáximo no ciclismo. Brazilian Journal of Biomotricity. Vol. 2. Num. 3. p. 195-203. 2008.

ALTIMARI, L. R., CYRINO, E. S., ZUCAS, S. M., OKANO, A. H., BURINI, R. C. Cafeína: ergogênico nutricional no esporte. Rev. Bras. Ciên. e Mov. Vol. 9. Num. 3. p. 57-64. 2001

ALTIMARI, L. R., CYRINO, E. S., ZUCAS, S. M., OKANO, A. H., BURINI, R. C. Efeitos ergogênicos da cafeína sobre o desempenho físico. Paul J Phys Educ. Vol. 14. Num. 2. p. 141-158. 2000

BORTOLOTTI, H.; PASQUARELLI, B. N.; SOARES-CALDEIRA, L. F.; ALTIMARI, L. R \& NAKAMURA, F. Y. Avaliação da capacidade de realizar sprints repetidos no futebol. Motriz, Rio Claro, v.16 n.4 p.1006-1012, out./dez. 2010.

FETT, C. Ciência da Suplementação Alimentar. Rio de Janeiro: Sprint, 2000.

GLAISTER, M., G. HOWATSON, J. The reliability and validity of fatigue measures during multiple-sprint work: an issue revisited. J Strength Cond Res, v.22, n.5, Sep, p.1597-601. 2008. Disponível em:http: //dx.doi.org/10.1519/ JSC.0b013e318181ab80. Acesso em: 07/11/2016.

KALMAR, J.M.; CAFARELLI, E. Caffeine: a valuable tool to study central fatigue in humans? Exercise and Sport Science Reviews. Vol. 32. Num. 4. p. 143-147. 2004.

KALMAR, J.M.; CAFARELLI, E; Effects of caffeine on neuromuscular function. J. Appl. Physiol. Vol. 87. Num. 2. p. 801-808. 1999. 
MCARDLE, W.D.; KATCH, F.I.; KATCH, V.L. Fisiologia do exercício-energia, nutrição e desempenho humano. Rio de Janeiro: Guanabara Koogan, 4o ed. 1998.

MELLO, D.; KUNZLER, D.K.; FARAH, M. Cafeina e seu efeito ergogênico. Revista Brasileira de Nutrição Esportiva. São Paulo v.1, núm.2 p. 30-37, Mar/abril, 2007.

RANG, H. P.; DALE, M. M. Farmacologia. Rio de Janeiro: Guanabara Koogan, 1993.

SILVA, Michel S. Os efeitos da cafeína relacionados à atividade física: uma revisão. Revista Digital - Buenos Aires - Ano 9 n66, 2003.

SILVEIRA, L.R.; ALVES, A.A.; DENADAI, B.S. Efeito da lipólise induzida pela cafeína na performance e no metabolismo de glicose durante o exercício intermitente. Rev. Bras. Cie. e Mov. Vol. 12. Num. 3.p. 21-26. 2004

SOARES, M.S.I.A.; FONSECA, R.M.B. Cafeína. Trabalho de Toxicologia e Análises Toxicológicas do Laboratório de Toxicologia da Faculdade de Farmácia da Universidade do Porto. 2004/05.

SPRIET, L.L. Caffeine and performance. Int. J. Sports Nutr. Vol. 5. Num. 1. p. 8499. 1995.

VITORINO, D.C.; e colaboradores. Efeitos da Ingestão Aguda de Cafeína sobre o Desempenho Anaeróbico Intermitente. Rev. Treinamento Desportivo. Vol. 8. Num. 1. p. 01-05. 2007.

WILMORE, J.H.; COSTILL, D.L. Fisiologia do Esporte e do Exercício. São Paulo: Manole, 1999. 